EGU2020-2763, updated on $14 \mathrm{Jul} 2020$

https://doi.org/10.5194/egusphere-egu2020-2763

EGU General Assembly 2020

(c) Author(s) 2020. This work is distributed under

the Creative Commons Attribution 4.0 License.

\title{
Preliminary geochemical characterization of gas manifestations in North Macedonia
}

\author{
Marjan Temovski ${ }^{1}$, Walter D'Alessandro ${ }^{2}$, Artur lonescu ${ }^{3,4}$, Lorenza Li Vigni ${ }^{2,5}$, Kata Molnár ${ }^{1}$, László \\ Palcsu', and Carlo Cardellini ${ }^{3}$ \\ ${ }^{1}$ Isotope Climatology and Environmental Research Centre, Institute for Nuclear Research, Debrecen, Hungary \\ ${ }^{2}$ Istituto Nazionale di Geofisica e Vulcanologia (INGV) - Sezione di Palermo, Italy \\ ${ }^{3}$ Dipartimento di Fisica e Geologia, Università di Perugia, Italy \\ ${ }^{4}$ Faculty of Environmental Science and Engineering, Babes-Bolyai University, Cluj-Napoca, Romania \\ ${ }^{5}$ Dip. Scienze della Terra e del Mare, Università di Palermo, Italy
}

Like most of the Balkan Peninsula, North Macedonia is a geodynamically active area. As such it has many hydrothermal features and gas manifestations. Until now, no systematic study about the geochemical characterization of the geogenic gases was made before in this country. In August 2019, 24 gas samples were collected in the study area. All, except one collected at Duvalo (soil gas), are gases bubbling or dissolved in thermomineral waters (temperatures from 12 to $66^{\circ} \mathrm{C}$ ). They were analysed in the laboratory for their chemical ( $\mathrm{He}, \mathrm{Ne}, \mathrm{Ar}, \mathrm{O}_{2}, \mathrm{~N}_{2}, \mathrm{H}_{2}, \mathrm{H}_{2} \mathrm{~S}, \mathrm{CH}_{4}$ and $\mathrm{CO}_{2}$ ) and isotopic composition $\left(\delta^{13} \mathrm{C}_{-}-\mathrm{CO}_{2}, \delta^{13} \mathrm{C}-\mathrm{CH}_{4}, \delta^{2} \mathrm{H}-\mathrm{CH}_{4}\right.$ and $\left.\mathrm{R} / \mathrm{R}_{\mathrm{A}}\right)$. Most of the gases have $\mathrm{CO}_{2}$ as the main component (400-998,000 ppm) while the remaining are enriched in $\mathrm{N}_{2}(1300-950,000 \mathrm{ppm})$. Helium ranges from 0.3 to $2560 \mathrm{ppm}$ while $\mathrm{CH}_{4}$ from 1.6 to $20,200 \mathrm{ppm}$. R/ $/ \mathrm{R}_{\mathrm{A}}$ and ${ }^{4} \mathrm{He} /{ }^{20} \mathrm{Ne}$ ratios indicate a generally low atmospheric contamination, a prevailing crustal contribution and mantle contributions between 1 and 20\% considering a MORB endmember. The highest mantle contributions are found in the SE part of the country very close to the sites that show the highest $R / R_{A}$ values in continental Greece [1]. This area is characterised by extensional tectonics and PlioPleistocene volcanism. A quite high mantle contribution (about 15\%) is also found in two manifestations in the NW part of the country along a main normal fault system. With the exception of the sample of Smokvica, which has very low $\mathrm{CO}_{2}(1400 \mathrm{ppm})$ and $\delta^{13} \mathrm{C}-\mathrm{CO}_{2}(-15.7 \%$ V-PDB), all free gases show a relatively narrow range in $\delta^{13} \mathrm{C}-\mathrm{CO}_{2}$ values $(-4.6$ to $+1.0 \%$ V-PDB) indicating the mixing between a mantle and a carbonate rock source. The isotope composition allows us to assign the $\mathrm{CH}_{4}$ origin to three sources. The largest group can be attributed to a hydrothermal origin $\left(\delta^{13} \mathrm{C}_{-} \mathrm{CH}_{4}\right.$ around $-20 \%$ V-PDB and $\delta^{2} \mathrm{H}-\mathrm{CH}_{4}$ around $-100 \%$ ). Three samples collected in the SW part of the country have a thermogenic origin $\left(\delta^{13} \mathrm{C}_{-}-\mathrm{CH}_{4}\right.$ around $-35 \%$ V-PDB and $\delta^{2} \mathrm{H}-\mathrm{CH}_{4}$ around $-160 \%$ V-SMOW). Finally, one sample (Smokvica) with the highest values $\left(\delta^{13} \mathrm{C}_{-} \mathrm{CH}_{4}-7.2 \% 0\right.$ V-PDB and $\delta^{2} \mathrm{H}-\mathrm{CH}_{4}-80 \%$ V-SMOW) may be attributed to abiotic processes in a continental serpentinization environment or to methane oxidation.

This research was funded by the DCO Grant n. 10881-TDB "Improving the estimation of tectonic carbon flux", GINOP-2.3.2-15-2016-00009 'ICER' project and PO FSE Sicilia 2014 - 2020 (CUP: 
G77B17000200009).

References:

[1] Daskalopoulou et al., 2018 - Chemical Geology, 479, 286-301 